\title{
FÓRIZS SÁNDOR
}

\section{Menekültügyi válsághelyzet 1947-ben}

Magyarország és a szomszédos országok a második világháború után rendkívül kedvezőtlen gazdasági és politikai viszonyok között kezdtek hozzá az életkörülmények normalizálásához, a háborús károk felszámolásához. Józan észszel, a logika mai szabályai szerint ezeknek az államoknak félre kellett volna tenniük minden korábbi ellenségeskedést, és új alapokon, egymással összefogva nekivágni a jövő építésének. A történelem ismételten megmutatta, az események nem az optimális megoldásokat követik, az elromlott kapcsolatok, a háború alatt szerzett és okozott friss sérelmek csak hosszabb idő alatt hozhatók rendbe. Talán nem felelötlenség, ha megfogalmazzuk, az 1946-1947-es csehszlovák-magyar kapcsolatokat a másik fél részéröl jelentős mértékben a leszámolás, bosszuállás, „törlesztés” gondolata motiválta.

Publikációmban a csehszlovák-magyar államhatáron az 1946-1947-es években kialakult, mai szóhasználattal menekültügyi válsághelyzetnek nevezhető események határrendészeti vonatkozásait szeretném a tisztelt olvasóval megismertetni. Nem kívánok nagyobb mélységben foglalkozni a történtek politikai részleteivel, csak amennyiben azok a határrendi kérdéseket érintették.

A menekültügyi válsághelyzettel mint rendészettudományi elméleti kategóriával, fogalommal, Gubicza József foglalkozott doktori értekezésében, ő alkotta meg a kapcsolódó, alkalmazható meghatározást: „,Menekültügyi válsághelyzet az az állapot, illetve időszak, amikor a menekülök viszonylag rövid idö alatti tömeges megjelenése és átáramlása az államhatáron indokolttá és szükségessé teszi az általánostól eltérő, kiegészitő vagy különleges intézkedések, rendszabályok bevezetését, a menekültügyi feladatok megoldásába más szervezetek bevonását."

A témához kapcsolódik még Görbe Attiláné Zán Krisztina PhD-értekezése a migráció jelenségéröl. ${ }^{2}$

\footnotetext{
1 Gubicza József: A BM Határőrség feladatai a Magyar Köztársaságra háruló menekültügyi feladatok megvalósításából. Egyetemi doktori értekezés. Zrínyi Miklós Katonai Akadémia, Budapest, 1992, 16. o. 2 Görbe Attiláné Zán Krisztina: A magyarországi migráció helyzete, kezelésének feltételei és lehetőségei. PhD-értekezés. Zrínyi Miklós Nemzetvédelmi Egyetem, Budapest, 2010
} 
Magyarország politikai, rendészeti mozgástere rendkívül behatárolt volt ebben az időszakban. Az események kezdetén még nem kötötték meg a háborút lezáró békeszerződést, hazánk megszállt államnak számított korlátozott, inkább jelképes fegyveres erőkkel. Az államhatár még ideiglenes demarkációs vonalnak minősült. Elvileg a normális határ menti kapcsolatok kiépítése lett volna napirenden, feladataival, mint a határforgalom újjászervezése, a kettősbirtokosok helyzetének rendezése, a kishatárforgalom és a határrend stabilizálása. A határterületen olyan áldatlan állapotok uralkodtak a csempészet, fegyveres rablóbandák tevékenysége, háborús menekültek és áttelepülők százezres nagyságrendü mozgása, keletről nyugati irányba húzódó fegyveres milíciák (vlaszovisták, banderisták, a lengyel Honi Hadsereg tagjai) nyomán, hogy az ember gondolhatná, elég ennyi probléma, nincs szükség újak teremtésére. És mégis, ilyen körülmények között a csehszlovák kormány belekezdett az államhatár szlovák oldalán az összefüggően magyar nemzetiség által lakott területekről a kisebbségi lakosság kitelepítésébe, áttelepítésébe, Csehszlovákiába és a Szudéta-vidékre. A cél az etnikai viszonyok végleges és alapvető megváltoztatása, úgymond, azzal a céllal, hogy a magyarok soha többé ne tarthassanak igényt ezekre a területekre. Az eseményekkel párhuzamosan már folyt a magyar-szlovák lakosságcsere, amely elvileg önkéntes volt, de olyan radikálisan nem változtatta volna meg a nemzetiségi összetételt, amennyire azt a csehszlovák kormány szerette volna. Az egyéves kötelező munkaszolgálat elrendelése és egész családok ehhez kapcsolódó kitelepítése menekülthullámot indított el az államhatáron keresztül hazánk irányába, ami egy teljesen természetes reakció, hiszen az érintettek sehol máshol nem találhattak menedéket. Mindamellett a kisebbség részleges és várhatóan végleges eltávozása beleillett a szomszéd állam hivatalos elképzeléseibe.

A magyar-csehszlovák államhatárral kapcsolatban (államhatár kialakulása, megjelölése, általános szabályok) az olvasó részletes további információkat szerezhet Sallai János könyvéböl. ${ }^{3}$

\section{A kitelepítések módszere}

A kitelepítés, a munkaszolgálatra történő elvitel végrehajtása, mivel ahhoz önkéntes jelleg jórészt nem kapcsolódott, az esemény természeténél fogva rendkívül durván történt. A csehszlovák katonaság és csendőrség bekerítette az érintett településeket. Hermetikusan körülzárták a falvakat. Ha az államhatár a közelben

3 Sallai János: Az államhatárok. Press Publika Kiadó, Budapest, 2004 
húzódott, azon is határzárat hoztak létre. Ilyenkor gyakran szüneteltették a kishatárforgalmat, hogy Magyarországról gazdálkodók ne léphessenek be, és a történteknek ne legyenek szemtanúi, ne vigyék ki az események hírét. A katonaság általában beszállásolta magát az iskolába, majd az utcákon járőrözni kezdtek. Éjszakára kijárási tilalmat rendeltek el, megtiltottak minden gyülekezést és megbeszélést, igyekeztek az érintetteket elszigetelni egymástól. Az előzetesen öszszeállított névjegyzékek alapján a községházába berendelték a családfőket, és átadták a kitelepítési határozatot, vagy egyenesen házhoz vitték, aláíratva az átvételt. Csomagolásra minimális időt hagytak. A munkaszolgálatosokat, gyakran az egész családot, fizikai erőszakkal tehergépkocsikra szállították, majd egy közeli vasútállomáson vagonokba zárták. Az ellenállás megtörése érdekében gyakran a levegőbe lövöldöztek, a gépjármüvek motorjait bőgették, elnyomva ezzel a védekezők kiabálását. Házról házra járva gyorsan kiürítették a kiszemelt épületeket. Az egész rettenetes módon hasonlított a háború alatti deportálásokhoz, és így az emberekben a legrosszabb érzéseket keltette. A gyerekek ruhájára az azonosító adataikat tartalmazó cédulákat kellett rögzíteni. Emiatt elterjedt a hír, a kicsiket a szülőktől elválasztják és nevelőotthonokba, nevelőszülőkhöz adják. A panaszok szerint különösen durván bántak és fizikai erőszakot alkalmaztak a kitelepítettekkel az úgynevezett „partizánok”. Ök azok, akik a háború alatt német- és magyarellenes harcokban vettek részt, és az új államgépezet kiépítésekor sokan közülük megbízhatóságukból kifolyólag a biztonsági szervekhez kerültek, magukkal hozva korábbi magyarellenességüket.

Az eseményekről a magyar belügyminiszternek pontos tudomása volt, ezt az egyik vaskos, több anyagot is tartalmazó iratgyüjtő is bizonyítja. ${ }^{4}$

A dosszié belső oldalán a miniszternek szóló jelenésben összefoglalják a legújabb információkat: „,Esztergomban tovább tart a határon túl élő magyarok menekülése. A menekülök a legkülönbözöbb vízi jármüveken kelnek át a Dunán, kétségbeesett helyzetükre jellemzö, hogy az átkelésre teljesen rossz állapotban lévö csónakokat, söt nagyobb teknöket is felhasználnak. Több esetben elöfordult, hogy a menekülök csónakjai a magyar part közelében elsüllyedtek. Menekültek elbeszéléseiböl megállapitható, hogy a csehszlovák határ mentén élö lakosság elszállitása továbbra is a legembertelenebb kegyetlenséggel történik. A muzslai kitelepités során elhurcolták Tóth Károly 82 éves muzslai (Hosszú sor 109) lakost és 70 éves feleségét is. Kömösi János és családja elszállitása során a felnötteket véresre verték, Ilonka nevü leányát pedig a hajánál fogva dobták fel az autóra."

4 Magyar Belügyminisztérium fejrészes dosszié. „Csehszlovákia területén élő magyar lakosság elleni intézkedések.” MNL HOP XIX-B-10. 1946. év 1. sz. doboz, IV./12 78. folyószám. 
Az egyik itt szereplő jelentés szerint „Folyó hó 16-án Köbölkút, Muzsla és Tárkányfalva községeket a csehszlovák katonaság körülkerítve megszállta. Az ottani magyarokat 30-kg-os csomaggal akarják a községekböl eltávolítani. Valószinüleg ma éjjel, mert a magyarok készenlétben vannak. Sokan megpróbáltak megszökni, ez ideig 15 öngyilkosság történt. A magyarokat állitólag Csehországba vagy a Szudéta Vidékre viszik."

November 20-án „A rajkai rendörőrs jelenti, hogy a délután folyamán, az est beálltával cseh területröl 75 család, kb. 150-200 fövel ladikon, a Dunán átjött Rajkára, mivel el akarták szállitani öket Morvaországba...”. „Rajkán vannak elhelyezve. Az éj folyamán a menekülők számának növekedésével lehet számitani."

Egy másik jelentés szerint egy személy bent járt Köbölkúton, ő hozta az információkat.

„,Kézbesitö iveket kell a kiértesitésröl mindenkinek aláírni. Ezt sokan eltépték. Az áttelepitést állitólag november 18-án kivánják kezdeni."

„A lakosság mindazon személye, aki magyarnak vallotta magát egy behivót kapott áttelepitésre Csehország belsejébe.” „A kézbesitó ivet saját kezüleg alá kellett irni, amelyet legtöbb személy megtagadott és megsemmisitett. Mindaz, aki az áttelepitést megtagadja 100000 cseh korona pénzbüntetés, vagy egyévi elzárásra büntetik."

Az emberek kaptak egy listát, hogy mit vihetnek magukkal. A gyerekekre cédulát kell tüzni, és nyakban hordani, ,atyja, anyja neve, gyermek születési éve, gyermek neve és utolsó lakhelye”. „Erröl az a hír terjedt el, hogy a gyerekeket külön táborba viszik, elszakitják a szülöktől."

Szerencse a szerencsétlenségben, a menekülők jelentős részének voltak magyarországi rokonaik, hiszen az államhatár tíz-tizenöt kilométeres körzetéről van szó. A többség így rokonokhoz mehetett, s ez jelentősen tehermentesítette az állami apparátust.

A kitelepítés településről településre haladt. 1946. december 22-én felfüggesztették, majd januárban újraindult.

1946. november 14-én a Külügyminisztérium kiadott egy körlevelet, amelyben figyelmeztette az illetékeseket a várhatóan bekövetkező eseményekre. „Folyó hó 14-én fordultak elö elöször olyan jelenségek, melyek arra engedtek következtetni, hogy a magyar határ mentén, csehszlovák területen élö magyarsággal szemben a csehszlovák hatóságok drasztikus intézkedéseket kívánnak foganatositani. ",

5 Magyar Belügyminisztérium fejrészes dosszié. „KÜM tájékoztató”. MNL HOP XIX-B-10. 1946, 1. sz. doboz, IV-12. 79. folyószám. 
November 18-án az esztergomi határrendészeti kapitányság észlelte, hogy Muzsla községet a katonaság körbezárta, 19-én pedig százötven-kétszáz menekült érkezett Rajkánál magyar területre.

November 17-én megkezdődtek a kitelepítések Köbölkút, Muzsla, Sárkányfalva községekből, hírek terjedtek öngyilkosságokról és halálesetekröl. A jelentésben feltünt egy érdekes mondat: „Az önként áttelepült és eltávozott szlovákok általában csalódottan visszaszökdösnek magyar területre, ezeket a csempészek segitik át."

\section{Események az államhatáron}

Szlovákiával szemben az államhatáron két szervezet is tevékenykedett az 1946-1947-es években, ezek érintve voltak a menekülési hullám kezelésében, és a jelentéseik a levéltári gyűjiőkben megtalálhatók. A Honvéd Határvadászok a „zöldhatárért” feleltek, valamint a kishatárforgalmi átkelést intézték. A határrendészeti kapitányságok az állami rendőrség részeként néhány nagyobb átkelőhelyen a távolsági határforgalmat ellenőrizték. A községekben a rendőrség és a közigazgatási hatóság intézte az átmenekültek ügyeit, elhelyezésüket, étkezést, nyilvántartásba vételt, kikérdezést, okmányokkal ellátást. Így több szervezetnek is bőséges és reális információi voltak a szomszédos viszonyokról. A két rendvédelmi szerv bizalmi személyeket is alkalmazott, akik a túloldalon laktak vagy hivatásszerúen átjártak, tőlük első kézből lehetett adatokat kapni. Az események befolyásolására viszont a hazai apparátusnak lényegében nem volt semmilyen eszköze, tehetetlenül kellett figyelniük a lezajló tragédiát.

A sok menekült ügyének rendezése nyilvánvalóan jelentősen leterhelte a hivatalos szerveket.

Ezt tükrözi egy december 14-én felterjesztett vastag iratgyüjtő, amelyben negyven név szerepel névjegyzékben Bajta, Leléd, Letkés, Bény, Szentendre, Ipolyszalka, G. páld községekből (utóbbi név ezzel az írással szerepel a jelentésben azonosítási lehetőség nélkül).

Valamennyi személyt meghallgatták a menekülés okáról, leltárt készítettek a magukkal hozott javaikról. Ebben az élő állaton, tehénen, lovas kocsin, élelmiszereken keresztül a legegyszerübb használati tárgyakig minden szere-

6 Jelentés a szobi határrendészeti kapitányságról. MNL HOPXIX-B-10. 1946, 1. sz. doboz, IV-12. 76. folyószám. 
pel (példa a 3. számú mellékletben). Az olvasó elképzelheti, milyen mennyiségü írásos munkát kellett végeznie az apparátusnak.

A kézzel írott meghallgatási jegyzőkönyvekből kitünik, hogy az érintettek megtudták, szerepelnek a kitelepítendők listáján, és a bizonytalanság elől kívántak elmenekülni. Többen is megjegyezték, hogy öt holdnál kevesebb a birtokuk, és a kiválasztásnál ez is egy szempont volt. A magyar rendőrség mostoha ellátási körülményei lemérhetők ezeken a meghallgatási jegyzökönyveken. Részben újságok üres oldalára kézzel írva készültek, mutatva, még papír sem állt a kívánt mennyiségben rendelkezésre.

Különleges esetek is előfordultak, amit a Külügyminisztérium által a honvédelmi miniszternek írt tájékoztatás is tükröz. ${ }^{7}$ Az 1947. februárban megküldött levél tárgya: „Magyar fegyveres banda feltartóztatása Csehszlovákiában”. Értesítik a minisztériumot, hogy a budapesti csehszlovák kormánydelegátus jegyzékben egy esetet említ, amelynél fegyveres magyar személyek átmentek szlovák területre ottani családokat kimenekíteni. Automata fegyverekkel harcba keveredtek a csehszlovák nemzetbiztonsági szervekkel, amelyek elfogtak egy magyar állampolgárságú hugyagi lakost (Balassagyarmati járás). A csoport két családot áthozott Kováčovce községböl. Az okmány kb. húsz tagú felfegyverzett „bandáról” ír, ami erős túlzásnak tünik, ennyi emberre azért nem lehetett szükség a családok kimentéséhez. Minden további nélkül elképzelhetö, hogy a határ másik oldaláról igyekeztek a rokonok mindent megtenni a bajbajutottakért.

A határon átmenő civilek által elkövetett fegyveres cselekmények nem voltak ismeretlenek az akkori igen rossz közbiztonsági helyzetben. Miután a szlovák külügyminisztérium jegyzékben tiltakozott, mert elmondásuk szerint felfegyverzett magyar állampolgárok automata fegyverekkel és kézigránáttal támadták meg a szlovák biztonsági szerveket „GNTOV” községben, a honvéd határôr-parancsnokság az események kivizsgálására és jelentéstételre kötelezte a 3. határvadász zászlóalj parancsnokságot. A felterjesztett jelentésben ${ }^{8}$ 1947. január 22-én az érintett zászlóalj kifejtette: a kérdéses időben a határvadászoknak sem automata fegyverük, sem kézigránátjuk nem volt. Szerintük az esetleges elkövetők Abasárról átjáró fegyveres csempészbandák lehettek, a szlovák fél által megadott községnév pedig hibás, nem lehetett be-

\footnotetext{
7 Dosszié. „Magyar fegyveres banda feltartóztatása Csehszlovákiában.” MNL HOP XIX-B-10. 1947. év 3. sz. doboz, 30. folyószám.

8 Jelentés. „Tárgy: Állítólagos magyar-csehszlovák határsértések kivizsgálása.” MNL HOP XIX-B-10. 1947. év 3. sz. doboz, 11. folyószám.
} 
azonosítani. Mindenesetre elkeserítő a helyzet, amikor a határőrök ismerik be, hogy a fegyveres csempészbandáknak jobb fegyverzetük van, mint nekik.

Az esemény egy későbbi jelentésben ismételten feltünik, de már más leírásban. A helyi határvadász század ismeretei szerint Szécsénykovácsi községből telepítették át az embereket a Szudéta-vidékre, ekkor menekültek öt lovas kocsival helyi lakosok, akiket a szlovák vámőrök közvetlenül az államhatárnál az itteniek szeme láttára feltartóztattak. Hugyag község lakói közül többen próbáltak a rokonoknak segíteni, és puskával kezdtek lövöldözni egymásra. Az eseményekbe beavatkozott két, a helyszínen szolgálatot ellátó magyar rendőr is a balassagyarmati kapitányságról, fegyveresen átlépve a határvonalat. A szlovák fél golyószóróval nyitott tüzet, egy személyt elfogott, és rendőreink csak nagy nehezen, lövöldözve vágták ki magukat a bajból. ${ }^{9}$

A két ország közötti rossz kapcsolatokat további nehezen megmagyarázható esetek is bonyolították. A Magyar Honvéd Határőr Parancsnokság levélben tájékoztatta a Külügyminisztériumot ${ }^{10}$, hogy 1947. május 5-én Csehszlovákiából ismeretlen felségjelzésủ repülőgép berepült a magyar légtérbe, és a határ menti községek felett nagy mennyiségü röplapot szórt le, majd Abaújvár határában elhagyta a magyar légteret. Háromezer röplapot összeszedtek és megsemmisítettek, egyet mellékeltek a levélhez az esetleges intézkedések megtétele céljából. A röplapban önálló Szlovákiát és önálló Kárpátalját követelnek. A röplap másolatban van csatolva a levéltári iratgyüjtőhöz, hitelességét aláírás és bélyegző bizonyítja. Az akkori magyar politikai vezetésnek semmilyen érdeke sem füződhetett egy ilyen jellegü akcióhoz, amely tovább rontotta a két ország közötti amúgy is kiélezett viszonyokat. A mozgatórugók vonatkozásában csak találgathatunk. A röplap szövegét a 2. számú melléklet tartalmazza.

Esztergomban a határrendészeti kapitányság vezetője, elmondása szerint, a november 22-i, 23-i, 24-i éjszakákon személyesen kiment a Duna-partra, és maga látta a meneküléseket. Volt, aki feleséggel, nagylánnyal, két kis ikergyerekkel jött át egy csónakon, amely már megtelt vízzel. Egy asszony az elmondása szerint Köbölkúton a vagonból szökött meg. A menekülők Párkány széléről indultak, és a víz többnyire az esztergomi vágóhídhoz sodorta őket. Egyesek megkísérelték a bútoraikat is átúsztatni a csónakok mögött.

A határőrség mozgástere rendkívül szük volt, hiszen a szlovák hatóságok ellen azok területén nem léphetett fel. Felterjesztésekkel „bombázták” a Kül-

\footnotetext{
9 Jelentés. „Rendörök által elkövetett jogtalan határátlépés és fegyveres erőszak tárgyában.” MNL HOP XIX-B-10. 1947. év 4. sz. doboz, 105. folyószám.

10 Tájékoztatás. „Tárgy: Csehszlovák eredetü röpcédulák a Felvidéken.” MNL HOP XIX-B-10. 1947. év 3. sz. doboz, 42. folyószám.
} 
ügyminisztériumot, és azok egy példányát megküldték a Szövetséges Ellenörző Bizottságnak. ${ }^{11}$

„, Gutor és Somorja között a csehszlovák katonaság lezárta az államhatárt. Aknavetö, géppuska, golyószóró megerösités. Többször átlöttek a magyar oldalra. Egy itteni csónakot megrongáltak. 90-100 magyar személy menekült át. Köztük egy sebesült. Menekül a magyar lakosság. Magyar járörre rálöttek, sebesülés nem volt."

Egymást érik a Budapestre felküldött távmondatok: ,, A Gutorszigeti állóörssel szemben a Csehszlovákok 1 géppuskát, aknavetöt, 1 golyószórót állitottak fel tüzkész állapotba. A Gutori járörre a 17/1 örs jör.-re Kaiseronál rálöttek géppisztollyal. Sebesülés nem volt.” „Dunacsunyba eddig 90-100 menekült személy érkezett. Elhelyezés a Község házán és családoknál. Elbeszélésük szerint a lakosságot kényszeritik a község elhagyására és aki ellenszegül össze verve és meg kötözve teher gépkocsikon viszik Somorjára és onnan vonattal Csehországba."

A Magyar Honvéd Határőrség Parancsnokságnak I-b. osztályára felterjesztették a B, azaz bizalmi személyektől összegyüjtött információkat 1946. december 13-án. ${ }^{12}$ Kitelepítésekröl jelentenek, Sajószárnya, itt hetven házból ötben maradhattak, Sajógömör, Gömörpatyit, menekültek lépték át az államhatárt Rimaszécs, Szentkirály, Abafalva, Borzova, Szilice körzetében. Aki aláirja a szlovák állampolgárságot, az állítólag maradhat. Felmérik az emberek hátrahagyott vagyonát, és papírt adnak róla. Jósvatapolcán besorozták és azonnal behívták az 1920 és 1926 között születetteket. A tizennyolc és negyven év közötti asszonyokat és tizennyolc és negyvenhat év közötti férfiakat viszik el munkára.

A felterjesztett január 29-i jelentés szerint január 26-án éjszaka Bussa községet (Kékkői járás) körbezárta a katonaság, csendőrök, partizánok, megkezdődött a kitelepítés. Embereket löttek agyon. A faluból negyven család menekült át Magyarországra Ludány községbe. Nógrádszakál községbe tizenöt család menekült. ,,Rárósmulyad községböl 27-én a hajnali órákban kezdték az elhurcolást. Itt is nyitott teherautókon szállitották a nagy hidegben a népet a Losonci vasútállomásra. Innen is szállitottak el 16 éven aluli fiú gyermekeket, olyan anyákat, akiknek 10 éven aluli gyermekük van, iparengedéllyel rendelkezö iparost, valamint betegeket és rokkantakat. Általában a szlovák hatósá-

\footnotetext{
11 Dosszié. „Emlékeztető.” Tárgy: „Fegyveres erőszak határzár és határmenti üzelmek Csehszlovák hatóságok által.” MNL HOP XIX-B-10. 1946. 1. sz doboz, IV-12. 69. folyószám.

12 „Jelentés a »B« egyénektől bejött információkról.” MNL HOP XIX-B-10. 1946. év 1. sz. doboz, IV-12. 70. folyószám.
} 
gok által kiadott 88/945 számú elnöki dekrétummal kiadott intézkedéseket egyáltalán nem vették figyelembe a végrehajtó közegek. A gyermekeket itt is szétválasztották a szülöktöl, valamint a férjet a feleségtöl is."

A 6. határvadász zászlóaljból november 19-én beküldött jelentés szerint ${ }^{14}$ a menekülő és csónakban ülő magyarokra a csehszlovák pénzügyőrök és katonák géppisztolyokból negyven-ötven méter távolságból tüzet nyitottak, Gutor községtöl délre. Schindler Ferenc meghalt, Lengyel Margit kabátját öt helyen lőtték át, csoda, hogy sértetlen maradt. A csónakot a szlovákok elfogták. A „határközi megbeszélésre” csak egy nappal később jelentek meg. Huszonöt-harminc ember próbált több csónakon átmenekülni, miután munkaszolgálatra behívták őket.

November 25-i dátummal egy rajkai lakos jelentését olvashatjuk, aki 21én Gutor szigetre ment magyar megbízásból, nyílt paranccsal mint hivatalos kiküldött, mégis egy időre őrizetbe vették. A határ menti tárgyalásra vitt egy hivatalos meghívót másodmagával.

„Az elhurcolt magyarokat kevés ingósággal teherautóra rakták és a szomorjai állomásra szállitották. [...] A kitelepitést végzö hatóságok azt hangoztatják, hogy a magyar családokat, csak ideiglenesen viszik el, jóllehet hátramaradt ingóságaikat azonnal széthurcolják és a helyükre szlovákokat telepitenek."

Elmondja, a Duna töltésén ötven-száz méterenként katona és csendőr áll. A községben legalább három század katona és hatvan csendőr tartózkodik, tábori konyhában föznek. „, A községben 45-50 db. katonai teherautó mozgott, akik a gutori magyarokat vitték és a telepes szlovákokat hozták. A kihurcolt magyarok házába már szlovákokat láttam."

Ilyen zürzavaros helyzetet nem lehetett könnyen kezelni. Különösen az akkori viszonyok között nem, amikor nem létezett egységes nyilvántartás, korlátozott volt a telefonon és táviratok útján történő érintkezés, hiányoztak a mai értelemben vett adatbázisok, amelyekben priorálni lehetett volna. A menekülteket az első kikérdezés után „menekültigazolvánnyal” látták el, mely okmányok kiadására a határrendőrség és a közigazgatási jegyzők voltak felhatalmazva. Ezzel az okmánnyal viszont az illető jogosult lett háromnégyszáz forint segély felvételére. A pénzt egyesek három helyen, Hatvanban, Budapesten, majd Debrecenben is felvették, majd esetleg visszamentek

\footnotetext{
13 Jelentés. „Szlovák deportálással kapcsolatos jelentés.” MNL HOP XIX-B-10. 1947. év 4. sz. doboz, 100. folyószám.

14 Jelentés a „Magyar 6. határvadász zászlóaljtól”. MNL HOP XIX-B-10. 1946. év 1. sz. doboz, III-4.55. folyószám.
} 
Szlovákiába. Azonnal megjelentek a katasztrófahelyzet vámszedői, ellenük nehézkes volt az eljárás. A Salgótarjáni Határrendészeti Kapitányság vezetöje jelentésében azt javasolta, hogy a jegyzők ne adhassanak ki igazolványt, csak a határrendőrség, mert véleménye szerint ezt a lehetőséget közülük is néhányan egyéni haszonszerzésre használják fel. ${ }^{15}$ Egyben tájékoztat: „,Határsávomban a menekülö családok száma elérte a 70-et."

Február 5-i jelentés: ,kitelepitettek Lukenyénye községböl 84 családot, Apátújfalu 22 családot, Nagycsalomja 20 családot”.

A határrendészeti kapitányságok 1947. februári helyzetjelentése szerint a Duna jegén négy-ötszázan jöttek át a hónapban.

A szomszédos országban zajló események befolyásolása céljából a magyar kormány áttelepülési tilalmat rendelt el a tölünk kivándorolni kívánó szlovákok tekintetében. Erre egy érdekes reakcióként jelentik a februári öszszesítésben, Oroszváron különbözö községekböl magyarországi szlovákok telepedtek le, hogy kikerüljék a magyar kormány áttelepülési tilalmát, megtudva, a békeszerződés értelmében Oroszvár községet hamarosan Szlovákiához csatolják. Ez be is következett, és 1947. október 11-i határidővel magát az Oroszvári Határrendészeti Kapitányságot is elköltöztették, mivel a három községet: Horvátjárfalu, Oroszvár, Dunacsuny, október 15-én 5 óráig át kellett adni Szlovákiának. A 65., 66., 67. határvadász őrsök is új helyükre kerültek a pozsonyi hídfőből.

A feszült kapcsolatok nyilvánvalóan mindkét oldal katonáinak a magatartásában jelentkeztek. Az egyszerü szolgálatban bekövetkezett áttévedéseknél is többször került sor súlyos sebesüléssel járó kölcsönös fegyverhasználatra, menekülők államhatáron átnyúló üldözésére. 1946. december 27-én Vámosmikolánál egy két embert üldöző szlovák katona magyar területre lépett az Ipoly jegén keresztül. Az ellene intézkedni szándékozó Benyák János határvadászt lefegyverezte, miközben fegyveréből lövést adott le, majd a jogtalanul fogságba ejtett katonát áthurcolták a túloldalra. A történtek egyik érdekessége, hogy mivel a visszaadást a helyi szervek megtagadták, a magyar határvadászok a bizottsági kivizsgálásba bevonták a szovjet városparancsnokság képviselöjét, és rajta keresztül érték el a katona visszaadását. ${ }^{16}$

A már átszökött személyek igyekeztek kapcsolatot tartani a kívül maradókkal olyan körülmények között, amikor lényegében nem volt határforga-

15 Jelentés. „Magyar nemzetiségü egyének deportálása Csehszlovákiában.” MNL HOP XIX-B-10. 1947. év 8. sz. doboz, 0532. folyószám.

16 Jelentés. „Hivatali titoksértés kivizsgálása.” MNL HOP XIX-B-10. 1946 1. sz. doboz, IV-12. 74. folyószám. 
lom. Maradt az illegális át- és visszalépés az államhatáron, az összes kapcsolódó kockázattal. Ezt tükrözi a 13/1. határvadász őrs jelentése. Az április 10én 21 órakor csónakban magyar területre átszökő két személy egyikét szlovák oldalról a Dunán agyonlőtték. Mindketten esztergomi lakosok voltak, és Párkányból jöttek, ahol a kint maradó rokonokkal találkoztak.

Májusban egy másik esetben a határőrség központi megkeresésre nyomozott Kunstár László budapesti lakos és társai holléte után. Nevezettek kimentek Szlovákiába vélhetően rokonok áthozatala céljából. A helyi 12. határvadász század megállapítása szerint az illetőt a szlovák határőrizeti szervek 1946. december 27-én agyonlőtték, és Bényben, az eredeti lakóhelyén eltemették. ${ }^{17}$

Nagybajcsnál december 22-én egy magyar házaspár, amely 1946 májusában települt át Magyarországra, és illegálisan ment vissza a gyerekeiért, már csehszlovák területen beszakadt a Duna jegén a vízbe, és mindketten életüket vesztették. A segítségükre sietőket is alig tudták kimenteni.

Az eseményekkel párhuzamosan zajlott a magyar-csehszlovák lakosságcsere, bár nem zökkenőmentesen. A felmerülő gondok miatt a Belügyminisztériumhoz tartozó Külföldieket Ellenőrző Országos Központi Hatóság körlevelet adott ki a járási és városi kapitányságok vezetőinek 1947 júliusában. ${ }^{18} \mathrm{Az}$ anyag szerint a szlovákok kitelepülésre jelentkezése és részükről az ország elhagyása teljesen önkéntes volt, és attól visszaléphettek. Ebben az időben már jelentős számú illegális visszaszivárgást jelentettek a hatóságok. Azokat, akik hivatalos szállítmánnyal az országot elhagyták, és okmányok nélkül visszajöttek, kitoloncolás céljából Budapestre kell szállítani a Külföldieket Ellenőrző Országos Központi Hatósághoz. A szlovák hivatalos szervek képviselői nálunk is széles körú nacionalista agitációt folytattak a szlovák származású lakosság körében az „őshazába” történő legális visszatelepülés érdekében. Nyilvánvalóan voltak, akik utólag csalódtak a körülményekben.

1947 közepére már több információ beérkezett a kitelepítettek további sorsáról, helyzetük alakulásáról. Az exodus továbbra sem állt le. A győri határvadász zászlóalj júliusban ötvenöt személy anyagát, meghallgatási jegyzőkönyveket terjeszt fel a Külföldieket Ellenőrző Országos Központi Hatósághoz. ${ }^{19}$

\footnotetext{
17 Jelentés. „Kunstár László és társainak agyonlövése Ipolynádasd és Letkés között.” MNL HOP XIXB-10. 1947. év 4. sz. doboz, 75. folyószám.

18 Dosszié. „A magyar-csehszlovák lakosságcsere egyezmény keretében Csehszlovákiába áttelepített és onnan visszaszivárgott személyek eltávolítása.” MNL HOP XIX-B-10. 1947. év 8. sz. doboz, 0558. folyószám.

19 Dosszié. „Menekültek jkv-inek felterjesztése.” 47. 08. 28., MNL HOP XIX-B-10. 1947. év 5. sz. doboz, 0347. folyószám.
} 
Ennél a szervezetnél kellett a menekülteknek letelepülési engedélyt kérniük. A kikérdezés formanyomtatvány szerint történt, amely a személyi adatokon kívül tartalmazza a menekülés okára és módjára vonatkozó nyilatkozatot, valamint a magyarországi letelepedéshez, munkába álláshoz kapcsolódó elképzeléseket. Sokan közülük már Csehszlovákia belsejéből jöttek vissza. Az áttelepülés leggyakoribb oka a további atrocitásoktól való félelem; családegyesítés, mivel a rokonság egyik fele már itt tartózkodik; munkahely és egzisztencia, iparüzési engedély és mühely elvesztése; a fiataloknál a magyar nyelvü tanulmányok folytatásának lehetősége. Gyakran házat, földet hagytak el, tervezik az otthon maradókért történő visszamenetelt. A korábban kitelepítettek Csehszlovákia belsejében, a mezőgazdaságban, vagy gyárakban kaptak elhelyezést, esetenként a házaspárok szétszakításával. A kereset nem fedezte a költségeket, a magukkal hozott javaik egy részét már útközben elveszítették, vagy később kénytelenek voltak eladni. Akadályozták őket a magyar nyelv használatában, még ott is, ahol üzemben sokan együtt voltak. Egy fiatal férfi már ledolgozott egy évet a Szudéta-vidéken Falkenauban egy karbidgyárban, a szülei megírták neki, „hogy a csehszlovák két éves terv keretében” el akarják vinni munkára, ekkor döntött úgy, hogy megszökik.

Egy családot Ciher nevü községbe vittek, rengeteg munka, nehéz megélhetés jellemezte a helyzetüket. Visszautaztak a falujukba, de a házukba már betelepítettek valakit, így két hét után, mert féltek a razziáktól, átjöttek, ház és föld ott maradt. Ami igazán lesújtó az általános helyzetben, hogy „,kitelepített sváb vagyont" szerettek volna kapni.

Az összetartás példája az az eset, amikor is egy család két lányát elvitték Csehszlovákiába, Police nad Metují községbe, textilgyárba dolgozni, a bátyjuk utánuk ment, és együtt szöktek Magyarországra. A meghallgatási jegyzökönyveket olvasva egyik tragikus történet a másik után bontakozik ki. Néhány személynél felmerül a nyilas múlt, a háború idején a Felvidék visszacsatolásakor kifejtett szlovákellenes magatartás, de a többség ezekben nem volt érintve, egyszerü földművesek, iparosok, fiatalok. Elmondás szerint elegendő volt, ha a családfő a „reszlovakizálási felhívást” megtagadta, valamelyik fiatalt elvitték tőlük az ország túlsó felére.

\section{Összegzés}

Az 1946-os év végén a szlovák-magyar államhatáron tipikus menekültügyi válsághelyzet alakult ki, amikor a csehszlovák kormány által kezdeményezett 
magyarellenes kitelepítések és munkaszolgálat elől az érintett lakosság részben hazánkba menekült. Ezzel egy időben már folyamatban volt a magyar-szlovák lakosságcsere, megnehezítve a határellenőrzést végző szervek munkáját. A körülményeket nehezítette a háború utáni szegénység, az állami szervek pénztelensége, létszámban és felszerelésben jelentkező hiánya. Az események befolyásolására a magyar félnek lényegében nem volt lehetősége, részben még a békekötés előtti időszakról van szó, és az országban müködő Szövetséges Ellenőrző Bizottság sem kívánt beavatkozni a történésekbe. Magyarországról több hullámban telepítették ki a német ajkú lakosságot, és ez sem szolgált jó alapul a tiltakozáshoz. A két ország rendészeti szervei között szintén megromlott a kapcsolat, vagy a háború után még nem is jött helyre. Ezáltal a határőrség képtelen volt a normális határrendi viszonyok kialakítására, éppen a másik fél ellenérdekeltsége miatt. A nehézségek számbavételekor arról sem feledkezhetünk meg, hogy az összes többi határviszonylatban is rendezetlenek és igen nehezek voltak a körülmények, lekötve a határörség erőit.

A menekülők helyzetének viszonylag gyors és rugalmas rendezését jelentős mértékben segítette a lakossági összefogás. A határ közvetlen közeléből, általában egy tíz-húsz kilométeres sávból származtak, és többnyire a magyar oldalon voltak közeli rokonaik, akik befogadták őket, valódi segítséget nyújtva a kezdeti nehézségek leküzdéséhez. Összességében mégis elmondhatjuk, a magyar államban megvolt a szándék az elmenekülők befogadására, ha azok magyar nemzetiségüek voltak, a körülményekhez képesti szerény anyagi támogatásra, a többség kapott letelepedési engedélyt.

A hivatalos magyar politikában is érvényesült bizonyos kétarcúság, amennyiben tiltakoztak a magyar lakosság Szlovákiából történő kitelepítése ellen, miközben ugyanez a sors várt a német nemzetiségre nálunk, illetve nem kívántuk befogadni az Erdélyből kiüzött szász és zsidó származású korábbi magyar állampolgárokat. 


\section{A kitelepítésre tervezettek részére átadott tájékoztató}

„Kormányunk az 1945. évi 88. számú elnöki dekrétum alapján 10 éves tervei keretén belül elrendelte az ország összlakosságára a kötelező munkaszolgálatot. Ezen kötelezettség Önöket is, leendő egyenjogú állampolgárokat terheli. Helyénvaló, hogy az ország építésének munkájában, mindnyájunk jólétének biztosítása érdekében részüket kivegyék.Ennek alapján országunk cseh területein, ahol legnagyobb a munkáshiány, lesznek munkába állítva. Anyagi kárt nem fognak szenvedni, és új munkahelyükön sokkal elönyösebb anyagi és kulturális viszonyok közé kerülnek, mint eddigi lakóhelyükön voltak.

A kötelező munkaszolgálat ideje 1 év s hogy munkahelyükre családostól lesznek kirendelve, történik a saját szociális érdekükben, hogy családjukkal együtt legyenek. Keresetüket, mely lényegesen előnyösebb eddigi jövedelmüknél, közösen és feltétlen megelégedésükre hasznosíthatják. Jövedelmük föbb pontjai a PrideLowacicimerben bennfoglaltatnak és minden igénybe vett munkaerő hetenként az ott felsoroltakat hiánytalanul megkapja.

Érdekeik legcsekélyebb megsértése esetén forduljanak az ott illetékes hatóságokhoz bizalommal s panaszaik azonnal orvosolva lesznek annál is inkább mert Kormányunk szigorúan súlyt helyez arra, hogy dolgozó polgárai megelégedését bírja, hogy a munkakedv fokozódását hozza magával. Kormányunkigazságos jó szándékáról új lakóhelyükön meg fognak győződni, ezért semmilyen ellenséges propagandának ne higyjenek." ${ }^{20}$

20 MNL XIX-B-10. 1947. év 8. sz. doboz, 0532. folyószám. „Tárgy: Magyar nemzetiségủ egyének deportálása Csehszlovákiában." 


\section{Az 1947. május 5-én ledobott röplap szövege}

„Követeljük

Az összes magyarlakta területek visszacsatolását!

Követeljük szlovák és ruszin testvéreink önállóságát, függetlenségét!

Éljen a megnagyobbodott Magyarország!

Éljen az önálló Szlovenszkó!

Éljen az önálló Podkarpatská Rusz!"’21

\section{3. számú melléklet}

\section{Leltár az egyes személyek magukkal hozott javairól. ${ }^{22}$}

Maksony József 1946. XII. 9-én felvett leltárjában szerepel:

$* 1 \mathrm{db}$. Tehén

* $45 \mathrm{~kg}$. Rozs

* $40 \mathrm{~kg}$. Árpa

* 25 kg. Kukorica

* $2 \mathrm{db}$. Féri öltöny

* $3 \mathrm{db}$. Nöi öltöny

* 5 pár Cipő

* 3 db Vánkos

* 2 db. Dunna

* $1 \mathrm{db} .7$ literes fazék

* 1 db. 3 literes fazék

* 3 db Tányér

* $1 \mathrm{db}$ Vizes veder

* $1 \mathrm{db}$. Mosdótál

* 1 db Gyúrótábla

* 1 db. Kerékpár

* 40 kg Sertéshús

21 MNL XIX-B-10. 1947. év 3. sz. doboz, 42. folyószám. Tájékoztatás. „Tárgy: Csehszlovák eredetű röpcédulák a Felvidéken."

22 Dosszié. „Magyar Honvéd Határőr Parancsnokságnak”. Vác 1946. dec. 14. „Csehszlovákiából menekült magyarokról felvett jegyzőkönyveket és névjegyzéket felterjesztem". MNL HOP XIX-B-10. 1946. év 1. sz. doboz, IV-12. 71. folyószám. 
